\title{
Whole grains and public health
}

\author{
(ब) (1) $\Theta$ OPEN ACCESS \\ Small increases in population intake could bring substantial benefits
}

\section{Cecilie Kyrø postdoctoral researcher, Anne Tjønneland head of research}

Danish Cancer Society Research Center, Strandboulevarden 49, 2100 Copenhagen, Denmark

Whole grains consist of the entire grain, and, unlike refined grains, they still contain bran, and germ, which are rich in dietary fibre and micronutrients. Whole grains were once neglected by researchers in favour of studies on dietary fibre, which found that cereal fibres were particularly healthy. ${ }^{1}$ As cereal fibres are found in whole grains together with micronutrients and phytochemicals, the focus of research shifted towards observational studies of whole grain intake. A large body of evidence on whole grains in relation to health outcomes has accumulated over the past 10 or 15 years.

In a linked article, Aune and colleagues (doi:10.1136/bmj.i2716) report on their meta-analysis of 45 cohort studies, showing that a higher intake of whole grains is associated with a lower risk of cardiovascular disease and total cancer and all cause and disease specific mortality. ${ }^{2}$ Several mechanisms could explain the association between intake and a lower risk of major diseases and death. Whole grains have beneficial effects on glucose-insulin homeostasis, blood lipids, and gastrointestinal health. ${ }^{3}$ The new meta-analysis, however, has several weaknesses, including poor information on the assessment of whole grain intake in many of the included studies and few studies for some endpoints such as mortality from diabetes and infectious diseases.

Future studies should improve the assessment of whole grain intake by reporting intakes in a similar way, ${ }^{4}$ using biomarkers to track compliance in randomised trials, and using validated assessment methods in observational studies. ${ }^{5} \mathrm{We}$ still need more and better research on the biological mechanisms of health effects and the contribution to health of different grain types. For instance, studies suggest that whole grain oats and rye might be more beneficial than whole grain wheat in relation to cardiovascular disease. ${ }^{6}$ In most countries, cereals are a major energy source, and surprisingly little attention has been paid to the quality of cereals in dietary recommendations - that is, whether they are refined or "whole." National guidance in Scandinavian countries recommends a whole grain intake of 75 $\mathrm{g} /$ day per $10 \mathrm{MJ}^{7}{ }^{\mathrm{UK}}$ guidance is much less specific, with advice to choose "whole grain, brown or high fibre varieties whenever you can." ${ }^{8}$ Currently, the whole grain intake in the
UK is far below the intake recommended in Scandinavian countries (fig 1).

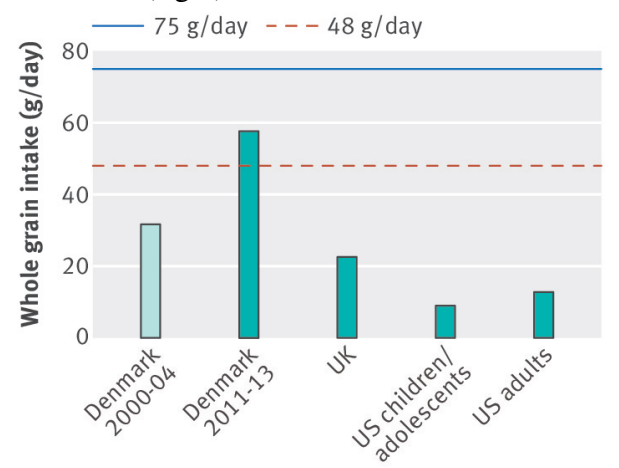

Fig 1 Whole grain intake in Denmark in people aged 4-75 in 2000-04 and 2011-13, ${ }^{9}$ in UK in people aged $>1.5$ in $2008-11^{8}$, and in US in children/adolescents and adults in 2009-10. ${ }^{10}$ Graph shows recommended intake by Scandinavian food and health authorities ( $75 \mathrm{~g} / \mathrm{day})$, and intake representing three servings (about $48 \mathrm{~g} /$ day or 90 $\mathrm{g}$ product/day). Intakes are measured as mean intake in $\mathrm{g} /$ day in Denmark, as median $\mathrm{g} /$ day/10 $\mathrm{MJ}$ in UK, and mean intakes calculated from ounce equivalents (about one serving)/day to g/day in US. One ounce equivalent/serving is equal to $16 \mathrm{~g} /$ day $^{411}$

Lessons can be learnt from Denmark, where the intake of whole grains has almost doubled over the past 10 years (fig 1). This improvement is thanks to the combined efforts of the food and health authorities, non-governmental organisations (NGOs), and industry. The Danish Whole Grain Partnership set product standards to ensure that foods granted a whole grain logo satisfied strict content criteria for at least a minimum amount of whole grain and less than the maximum allowable amounts of added sugar and salt. ${ }^{12}$

If and when other countries follow Scandinavia's lead and set specific recommendations for whole grain intake, the authorities should take great care not to promote whole grain foods with high sugar and salt content. These food items could attenuate 
any subsequent health benefits. In a recent study on whole grain intake in the UK, children and adolescents with the highest intake of whole grains also had the highest intake of sugar. ${ }^{13}$

Aune and colleagues report reductions in risk associated with whole grain intakes of up to 7.5 serving a day. ${ }^{2}$ Even in Denmark, a country with one of the highest whole grain intakes in the world, only about $6 \%$ of people currently consume seven or more servings. ${ }^{9}$

This level of dietary intake might be ambitious, but it is feasible. Effective campaigns and product development can lead to large increases in whole grain intake. The largest health benefit might be achieved simply by shifting people from low or no intake of whole grains to an intake of just one serving (16 g/day, such as $16 \mathrm{~g}$ of whole grain wheat, or $30 \mathrm{~g}$ product/day, such as $30 \mathrm{~g}$ of whole grain wheat bread $^{4}$ ). These small individual improvements could have a relatively large effect across whole populations. If we assume the associations reported by Aune and colleagues are causal, which research in general certainly supports, increasing whole grain intake could have a substantial and positive effect on public health in the UK and elsewhere through reductions in both morbidity and mortality.

Competing interests: We have read and understood the BMJ Group policy on declaration of interests and declare the following interests: None.

Provenance and peer review: Commissioned; not externally peer reviewed.

Aune D, Chan DS, Lau R, et al. Dietary fibre, whole grains, and risk of colorectal cancer: systematic review and dose-response meta-analysis of prospective studies. BMJ 2011;343:d6617. doi:10.1136/bmj.d6617 pmid:22074852.
2 Aune D, Keum N, Giovannucci E, et al. Whole grain consumption and risk of cardiovascular disease, cancer, and all cause and cause specific mortality: systematic review and dose-response meta-analysis of prospective studies. BMJ 2016;353:i2716.

3 Ye EQ, Chacko SA, Chou EL, Kugizaki M, Liu S. Greater whole-grain intake is associated with lower risk of type 2 diabetes, cardiovascular disease, and weight gain. $J$ Nutr 2012;142:1304-13. doi:10.3945/jn.111.155325 pmid:22649266.

4 Ross AB, Kristensen M, Seal CJ, Jacques P, Mckeown NM. Recommendations for reporting whole-grain intake in observational and intervention studies. Am J Clin Nutr 2015;101:903-7. doi:10.3945/ajen.114.098046 pmid:25809851.

5 Kyrø C, Olsen A, Landberg R, et al. Plasma alkylresorcinols, biomarkers of whole-grain wheat and rye intake, and incidence of colorectal cancer. J Natl Cancer Inst 2014;106:djt352. doi:10.1093/jnci/djt352 pmid:24317181.

6 Helnæs A, Kyrø C, Andersen I, et al. Intake of whole grains is associated with lower risk of myocardial infarction: the Danish Diet, Cancer and Health Cohort. Am J Clin Nutr 2016;103:999-1007. doi:10.3945/ajcn.115.124271 pmid:26888710.

7 Kyrø C, Skeie G, Dragsted LO, et al. Intake of whole grain in Scandinavia: intake, sources and compliance with new national recommendations. Scand J Public Health 2012;40:76-84. doi:10.1177/1403494811421057 pmid:21976053.

8 Mann KD, Pearce MS, McKevith B, Thielecke F, Seal CJ. Low whole grain intake in the UK: results from the National Diet and Nutrition Survey rolling programme 2008-11. Br J Nutr 2015;113:1643-51. doi:10.1017/S0007114515000422 pmid:25904034.

9 National Food Institute. Technical University of Denmark (DTU): The whole-grain intake of Danes 2011-2013 [Danskernes fuldkornsindtag 2011-2013]. http://www.food.dtu.dk/ english//media/Institutter/Foedevareinstituttet/Publikationer/Pub-2014/Danskernes_ fuldkornsindtag_2011-2013.ashx

10 Reicks M, Jonnalagadda S, Albertson AM, Joshi N. Total dietary fiber intakes in the US population are related to whole grain consumption: results from the National Health and Nutrition Examination Survey 2009 to 2010. Nutr Res 2014;34:226-34. doi:10.1016/j. nutres.2014.01.002 pmid:24655489.

11 Oldways Whole Grains Council. What is an Ounce Equivalent? www.wholegrainscouncil. org/whole-grains-101/what-is-an-ounce-equivalent.

12 Danish Whole Grain Partnership. www.fuldkorn.dk/english

13 Mann KD, Pearce MS, McKevith B, Thielecke F, Seal CJ. Whole grain intake and its association with intakes of other foods, nutrients and markers of health in the National Diet and Nutrition Survey rolling programme 2008-11. Br J Nutr 2015;113:1595-602. doi: 10.1017/S0007114515000525. pmid:25893512.

Published by the BMJ Publishing Group Limited. For permission to use (where not already granted under a licence) please go to http://group.bmj.com/group/rights-licensing/ permissions

This is an Open Access article distributed in accordance with the Creative Commons Attribution Non Commercial (CC BY-NC 3.0) license, which permits others to distribute, remix, adapt, build upon this work non-commercially, and license their derivative works on different terms, provided the original work is properly cited and the use is non-commercial. See: http://creativecommons.org/licenses/by-nc/3.0/. 